\title{
Isolation of an IHF-deficient mutant of a Pseudomonas aeruginosa mucoid isolate and evaluation of the role of IHF in algD gene expression
}

\author{
Ina Delic-Attree, Bertrand Toussaint, Alexandra Froger, John C. Willison \\ and Paulette M. Vignais
}

Author for correspondence: Bertrand Toussaint. Tel: +3376883483 . Fax: +3376885185 .
e-mail: BT@girose.ceng.cea.fr

CEA/Grenoble, Laboratoire de Biochimie Microbienne (CNRS URA 1130 alliée à I'INSERM), DBMS, 17 rue des Martyrs, 38054 Grenoble Cedex 9, France

\begin{abstract}
The role of integration host factor (IHF) in the regulation of alginate synthesis was investigated in a mucoid strain of Pseudomonas aeruginosa (strain CHA) isolated from a cystic fibrosis patient. Escherichia coli strain BL21(DE3) was made IHF-deficient by inactivation of its chromosomal IHF genes, himA and himD, then used as host strain to overproduce $P$. aeruginosa IHF. The purified recombinant IHF protein was used to determine the affinity of IHF for the two IHF binding sites in the algD promoter. The $K_{\mathrm{d}}$ values were determined to be $130 \mathrm{nM}$ for algD IHF site 2 and about $2 \mu \mathrm{M}$ for algD IHF site 1. Two IHF-deficient mutants of $P$. aeruginosa strain CHA were constructed by insertional inactivation of the himA gene, and the activity of the algD promoter was determined using transcriptional fusion with xylE as reporter gene. The expression of algD, the structural gene for GDP-mannose dehydrogenase, was decreased three- to fourfold in the himA mutants under conditions of high salinity and nitrogen limitation. Assays of alginate production by cultures grown on agar plates indicated that the IHF-deficient mutants synthesized $\mathbf{5 0} \%$ less polymer than the mucoid parental strain. These results demonstrate clearly that although IHF is dispensable for alginate production, himA expression is required for full activation of algD expression.
\end{abstract}

Keywords: alginate, integration host factor, cystic fibrosis, Pseudomonas aeruginosa

\section{INTRODUCTION}

The overproduction of alginate by strains of Pseudomonas aeruginosa that chronically infect cystic fibrosis (CF) patients is an important virulence factor in these infections. It has been shown that the polysaccharide capsule promotes adherence to the epithelial cells of the respiratory tract (May et al., 1991), inhibits phagocytosis (Krieg et al., 1988) and protects the bacteria from certain antibiotics (Slack \& Nichols, 1981). Overproduction of alginate confers a mucoid phenotype upon colonies; strains that initially cause infections of the respiratory tracts of CF patients are typically non-mucoid, but with the progression of the disease, mucoid variants emerge and become predominant.

Most of the genes involved in alginate biosynthesis are clustered at $34 \mathrm{~min}$ on the $P$. aeruginosa chromosome and

Abbreviations: CF, cystic fibrosis; IHF, integration host factor. probably form a single operon (Chitnis \& Ohman, 1993; reviewed by May \& Chakrabarty, 1994a). The first gene of the cluster, algD, codes for GDP-mannose dehydrogenase, which catalyses the unidirectional oxidation of GDP-mannose to GDP-mannuronic acid, the immediate precursor of alginate. Transcription of the alginate biosynthetic cluster, preceded by algD, is controlled by a complex regulatory network. Activation of algD has been observed only in mucoid $P$. aeruginosa variants and correlates directly with alginate production. Various environmental conditions, such as high osmolarity, nitrogen or phosphate starvation, and ethanol-induced dehydration, promote the activation of alg $D$ transcription (May \& Chakrabarty, 1994a).

The algD promoter has a complex structure and DNA topology may play an important role in transcriptional regulation of the $\operatorname{alg} D$ gene. At least two histone-like elements appear to be involved, namely AlgP (AlgR3) (Deretic \& Konyecsni, 1990; Kato et al., 1990) and 
integration host factor (IHF). Indeed, IHF consensus sequences able to bind purified IHF from Eschericbia coli have been identified within the $\operatorname{alg} D$ promoter. Recently, Wozniak (1994) has shown, by mutational analysis of the algD promoter, that the IHF-binding sites are cis-acting elements required for high level alg $D$ transcription. It was therefore of interest to determine directly the effect of inactivation of the IHF genes on algD expression and alginate synthesis.

In a previous study, we demonstrated that $P$. aeruginosa contains IHF protein, which was purified from the mucoid strain CHA and shown to bind to the algD promoter in vitro (Toussaint et al., 1993a). More recently, we have reported the isolation and sequencing of the structural $\operatorname{bim} A$ and $\operatorname{bim} D$ genes, which encode the two IHF subunits (Delic-Attree et al., 1995). In the present study, we overproduced $P$. aeruginosa IHF in $E$. coli and determined the in vitro affinity of IHF for the algD promoter. In addition, we constructed an IHF-deficient mutant of the mucoid $P$. aeruginosa strain $\mathrm{CHA}$, and obtained direct in vivo evidence for the involvement of $\mathrm{IHF}$ in alginate synthesis.

\section{METHODS}

Media and growth conditions. E. coli strains were grown on LB medium (Sambrook et al., 1989) supplemented with tetracycline $\left(10 \mu \mathrm{g} \mathrm{ml}^{-1}\right)$, ampicillin $\left(100 \mu \mathrm{g} \mathrm{ml}^{-1}\right)$, kanamycin $\left(25 \mu \mathrm{g} \mathrm{ml}^{-1}\right)$ or chloramphenicol $\left(12 \cdot 5 \mu \mathrm{g} \mathrm{ml}^{-1}\right)$. P. aeruginosa strain CHA, a mucoid CF isolate obtained from the Centre Hospitalier Universitaire of Grenoble was grown in LB liquid medium or on Pseudomonas Isolation Agar (PIA; Difco) plates. The medium was supplemented with the appropriate antibiotics: tetracycline, $300 \mu \mathrm{g} \mathrm{ml}^{-1}$ for PIA plates and $100 \mu \mathrm{g} \mathrm{ml}^{-1}$ for LB medium; carbenicillin, $1 \mathrm{mg} \mathrm{ml}^{-1}$ for PIA and $300 \mu \mathrm{g} \mathrm{ml}^{-1}$ for LB. The minimal medium used was that of Vogel \& Bonner (1956). All cultures were grown aerobically at $37^{\circ} \mathrm{C}$.

Construction of an IHF-deficient $E$. coli host strain for overproduction of heterologous IHF. A derivative of $E$. coli BL21(DE3), which is used as a host strain for expression systems based on the T7 phage promoter (Studier et al., 1990), was constructed as follows. Strains JRY827 (LE392, bimD : : $\operatorname{cam}^{\mathbf{R}}$ ) and JRY826(LE392, bim A : : Tn10) were infected with the transducing phage P1 vir, as described by Miller (1972). Strain BL21(DE3) (Novagen) was then infected first with phage from JRY827, with selection for chloramphenicol resistance, then with phage from JR826, with selection for both chloramphenicol and tetracycline resistance. The resulting strain, JW186 [BL21(DE3), bim $\left.A:: \operatorname{Tn} 10, \operatorname{bim} D:: \mathrm{cam}^{\mathrm{R}}\right]$, was resistant to $10 \mu \mathrm{g}$ tetracycline $\mathrm{ml}^{-1}$ on agar plates, but not in liquid medium. Colony formation generally required $48 \mathrm{~h}$ incubation, compared to $<24 \mathrm{~h}$ for the parental strain. Strain JW186 lost viability rapidly upon storage at $-20^{\circ} \mathrm{C}$, but was stable for up to 12 months at $-80^{\circ} \mathrm{C}$. This strain could not be rendered competent by the standard $\mathrm{CaCl}_{2}$ method, and was therefore transformed by electroporation. The latter procedure was carried out in a Bio-Rad Gene Pulser Unit, using the manufacturer's recommended conditions.

Nucleic acid methodology. Restriction enzymes, DNA polymerase I (Klenow fragment) and T4 DNA ligase were purchased from Boehringer Mannheim. Treatment of DNA with enzymes, subcloning of DNA and transformations were performed as described by Sambrook et al. (1989). PCR reactions were done with Taq DNA polymerase (Promega), as recommended by the manufacturer. Plasmid DNA was purified with Qiagen columns (Qiagen Corp.). Southern blot hybridizations and detections were performed as described in the Boehringer Mannheim manual with digoxigenin-labelled DNA probes. DNA sequencing was performed by the chain-termination method (Sanger et al., 1977) using a Sequenase DNA sequencing kit (United States Biochemical) and $\left[{ }^{35} \mathrm{~S}\right] \mathrm{dATP} \alpha \mathrm{S} \quad\left(1000 \mathrm{Ci} \mathrm{mmol}^{-1}\right.$, $37 \mathrm{TBq} \mathrm{mmol}^{-1}$; Amersham).

Overproduction and purification of $\boldsymbol{P}$. aeruginosa IHF. To construct the overexpression vector pAF9, the $\operatorname{bim} A$ and $\operatorname{bim} D$ genes of $P$. aeruginosa were first amplified by PCR, using plasmids pIA281 and pIA3 (Delic-Attree et al., 1995) as templates. The primers used for amplification of $\operatorname{bim} A$ were OIP2 5'AACATATGGGGGCTCTGACGAA and OIP1 5'GGCTAAGGGCCGTTCGAACA. The 338 bp NdeIHindIII fragment so generated was cloned in pGEM- $T$ (Promega) to give pGTa. The primers OIP4 5'GCAAGCT'TGAAAAAGAAAGGGAAA and OIP3 5'CGGCCTCACTATAGCCTAGGCA were used to amplify the $\operatorname{bim} D$ gene. They generated a $329 \mathrm{bp}$ HindIII-BamHI fragment which was cloned in pGEM-T to give pGTb. The integrity of the inserts in pGTa and $\mathrm{pGTb}$ was verified by DNA sequencing. Next, the NdeIHindIII and HindIII-BamHI fragments from pGTa and pGTb, respectively, were cloned together in pET-9 (Studier et al., 1990) resulting in plasmid pAF9, in which the $\operatorname{bim} A$ and $\operatorname{bim} D$ genes are under the control of the strong bacteriophage T7 transcription and translation signals. For overexpression, E. coli JW186 harbouring pAF9 was grown aerobically at $37^{\circ} \mathrm{C}$ in $200 \mathrm{ml}$ SOC medium (Sambrook et al., 1989). Induction was initiated at an $\mathrm{OD}_{660}$ of 0.6 by the addition iof $1 \mathrm{mM}$ IPTG. IHF was obtained by the two-step purification procedure previously described (Toussaint $e t$ al., 1993b).

DNA binding assays and affinity measurements. DNA binding assays were performed essentially as described by Toussaint et al. (1993b). When using crude extracts in gel-shift experiments, a DNA fragment containing the high-affinity binding site of the algB promoter (Wozniak \& Ohman, 1993) was used, since in the case of the alg $D$ promoter, crude extracts contained additional proteins that gave rise to a shift similar to that produced by IHF. The DNA fragment containing the algB promoter was prepared by PCR, using primers $5^{\prime}$ AGCTAAGCT'TACCGCCTCGGGGCC and 5'TACGAATTCCACGGATGGCTCCGGGT and genomic DNA from strain CHA as template. A $280 \mathrm{bp}$ fragment extending from -158 to $+122 \mathrm{nt}$ relative to the transcription start point of $\operatorname{alg} B$ was generated. The algD fragment containing both IHF sites, generated by PCR reaction, was a 486 bp fragment extending from -290 to $+196 \mathrm{nt}$ relative to the algD start of transcription. Following electrophoresis, the gel was dried and exposed to a storage PhosphorScreen which was then introduced in a PhosphorImager apparatus (Molecular Dynamics) for image treatment. For the affinity measurements, total counts from both free DNA and DNA-IHF complex were determined and used to calculate the fraction of free DNA at each IHF concentration. These values were plotted on a graph showing the fraction of free DNA as a function of IHF concentration. The IHF concentration at which $50 \%$ of DNA was complexed $\left(K_{d}\right)$ was then estimated from this graph.

Construction of a himA mutant of $P$. aeruginosa. Analysis of the complete nucleotide sequence of the $1.8 \mathrm{~kb}$ HindIII insert of pIA281, containing the wild-type $\operatorname{bim} A$ gene, revealed no convenient unique restriction site in $\operatorname{bim} A$ for its insertional inactivation. Therefore, the following strategy was adopted. The $3^{\prime}$ and $5^{\prime}$ flanking regions of $\operatorname{bim} A$ were amplified in two separate PCR reactions. The oligonucleotides used to amplify 
IHF and alginate synthesis in $P$. aeruginosa

the $5^{\prime}$ flanking region were $\mathrm{M} \alpha 1$ 5'ACCCGGGGCAGACCGCGCGC, which anneals 60-80 nt downstream from the PstI cloning site and contains a $S m a \mathrm{I}$ site (underlined) at its $5^{\prime}$ end, and M $\alpha 2$ 'TGGATCCGCAATTTCAGCTTTCG, which is complementary to nt 14-32 downstream from the initiation codon of $\operatorname{bim} A$ and has a $B a m \mathrm{HI}$ site introduced at its $5^{\prime}$ end. PCR amplification with $M \propto 1$ and $M \propto 2$ generated a unique product of $490 \mathrm{bp}$ that was cloned in pGEM-T (Promega), to give pIA30. Amplification of the $3^{\prime}$ flanking region was performed with $\mathrm{M} \alpha 3$ (5'AGGATCCCGATCACGGCCCGCCG), which anneals to nt 214-223 downstream from the ATG codon and has a Bam HI site introduced at the $5^{\prime}$ end, and with $\mathrm{M} \alpha 4$ (5'CCTGCAGATGGAGGATGA), which is complementary to the sequence at and just upstream of the second PstI cloning site of pIA281. PCR amplification with primers $M \alpha 3$ and $M \alpha 4$ generated an $845 \mathrm{bp}$ fragment that was cloned in pGEM-T, giving pIA31. The two PCR fragments were ligated together in pGEM-T, generating the plasmid pIA32. In this construct a 181 bp internal part of the gene was removed and a unique BamHI site was created. Next, a $1.4 \mathrm{~kb}$ AvaI-EcoRI fragment containing the tet gene from pBR322 was blunt-ended with the Klenow enzyme and was ligated into the blunt-ended Bam HI site of pIA32. The orientation of tet was determined by restriction analysis, and two plasmids, pIA33A and pIA33B, differing with respect to the orientation of the tet gene, were selected. To carry out gene replacement as described by Schweizer (1992), the SmaI-PstI inserts from pIA33A and pIA33B were subcloned into pNOT19. Next, the MOB cassette from $\mathrm{pMOB} 3$ was cloned into the unique NotI site of the pNOT19 derivatives. The two resulting suicide plasmids, pIA35A and pIA35B, were then transferred to $P$. aeruginosa CHA by triparental conjugation, using pRK2013 as a helper plasmid (Konyecsni \& Deretic, 1988). For complementation experiments, a $1.8 \mathrm{~kb}$ HindIII fragment containing the wildtype $\operatorname{bim} A$ gene was extracted from pIA281 (Delic-Attree et al., 1995) and cloned into pUCP20 (West et al., 1994).

Immunoblotting experiment. E. coli and $P$. aeruginosa cultures were grown overnight in $30 \mathrm{ml} \mathrm{LB}$ medium. Cells were harvested by centrifugation and lysed by sonication in $50 \mathrm{mM}$ Tris/ $\mathrm{HCl}, 20 \mathrm{mM}$ EDTA buffer, $\mathrm{pH} 8$. Cell extracts were subjected to PAGE $(0 \cdot 1 \%$ SDS, $16 \%$, w/v, polyacrylamide) (Laemmli, 1970) in Tris/Tricine buffer, pH 8. The proteins were then transferred to the nylon membrane by electroblotting and filters were probed with antibodies against $E$. coli IHF. The bound antibodies were detected by chemiluminescence using an ECL kit (Amersham). Bands were scanned with an Arcus II scanner (AGFA) and analysed with ImageQuant software (Molecular Dynamics).

Alginate determination and XylE activity. Alginate was obtained from cells grown on solid PIA medium. Approximately the same number of cells $\left(10^{8}\right)$, grown overnight, was spread on plates and incubated for $24 \mathrm{~h}$ at $37^{\circ} \mathrm{C}$. Bacteria were scraped from the plates and resuspended in $0.9 \% \mathrm{NaCl}$. Alginate was measured in supernatant fluids after centrifugation $(12000 \mathrm{~g}, 30 \mathrm{~min})$ by the borate/carbazole method (Knutson \& Jeanes, 1968; May \& Chakrabarty, 1994b). Purified alginate (Sigma) was used as a standard. To constuct plasmid pIA111 carrying the algD-xylE transcriptional fusion, the algD promoter from pVD2X (Deretic et al., 1987) was subcloned as a HindIII-XhoI fragment in pVDX18 (Konyecsni \& Deretic, 1988 ). The activity of the $x y / E$ reporter gene was determined in supernatants after centrifugation at $12000 \mathrm{~g}$ for $15 \mathrm{~min}$ as described by Konyecsni \& Deretic (1988); one milliunit of catechol 2,3-dioxygenase corresponds to the formation at $25^{\circ} \mathrm{C}$ of $1 \mathrm{nmol} 2$-hydroxymuconic semialdehyde $\mathrm{min}^{-1}$. Protein concentrations were determined by the method of Bradford
(1976) using bovine serum albumin, fraction V (Sigma), as a standard.

\section{RESULTS}

\section{Overproduction and purification of $\boldsymbol{P}$. aeruginosa IHF}

To overproduct $P$. aeruginosa IHF in E. coli, the $\operatorname{bim} A$ and bim $D$ genes, previously cloned from strain CHA (DelicAttree et al., 1995), were independently amplified by PCR and subcloned in the pET-9 expression vector. The resulting plasmid, pAF9, was introduced into strain JW186, a derivative of E. coli BL21(DE3), in which the chromosomal him $A$ and $\operatorname{bim} D$ genes had been inactivated. By using a host strain unable to synthesize E. coli IHF, the purification of $P$. aeruginosa IHF was achieved without interference from the homologous $E$. coli protein. We checked by a gel-mobility shift assay that crude extracts prepared from JW186 did not contain active IHF (Fig. 1a, lane 2); in contrast, when crude extracts were prepared from strain JW186 harbouring pAF9, a stable complex due to IHF was obtained (Fig. 1a, lane 3). Strain JW186 has also been used to overproduce IHF from Rhodobacter capsulatus (unpublished work) and should have general use as host strain for the overproduction of wild-type or mutant IHF proteins from a wide range of bacteria.

The purification of IHF from strain JW186(pAF9) was achieved by the two-step procedure of Toussaint et al. (1993b). Extracts of cells from an IP'TG-induced culture were first loaded onto a heparin-Sepharose column, and the proteins were eluted by using a linear gradient of 0-1 $\mathrm{M} \mathrm{NaCl}$. This resulted in a high degree of purification of IHF, which was contained in the $0.8 \mathrm{M} \mathrm{NaCl}$ fraction (Fig. 1b, lane 2). However, this fraction, as analysed by SDS-PAGE and staining with silver nitrate, contained a major contaminant with a molecular mass of $15 \mathrm{kDa}$. This contaminant was eliminated by passage of the fraction through a Mono-S cation-exchange column, from which pure IHF was eluted at between 0.44 and $0.48 \mathrm{M} \mathrm{NaCl}$ (Fig. 1b, lane 4). The yield of the purification procedure was estimated to be $0.5 \mathrm{mg}$ IHF per litre of induced culture.

\section{Binding of $\boldsymbol{P}$. aeruginosa IHF to the algD promoter}

Two IHF binding sites have been identified within the promoter of the $P$. aeruginosa alg $D$ genes, one of which (site 1) spans positions -80 to -68 relative to the algD transcriptional start point, and the other of which (site 2) is located downstream from the transcription start point, at positions +79 to +105 . The affinity of site 1 for IHF from E. coli was previously found to be about two orders of magnitude lower than the affinity of site 2 (Wozniak, 1994). In the present study, we determined the affinity of purified IHF protein from $P$. aeruginosa for the two algD IHF binding sites. The $K_{\mathrm{d}}$ for algD site 1 was found to be about $2 \mu \mathrm{M}$ and the $K_{\mathrm{d}}$ for site 2 was $130 \mathrm{nM}$ (data not shown). With the fragment containing both algD sites, a unique complex was observed (Fig. 2), with a $K_{\mathrm{d}}$ for IHF of $130 \mathrm{nM}$, identical to that obtained with the fragment containing site 2 alone; this suggests that only site 2 was 
(a)

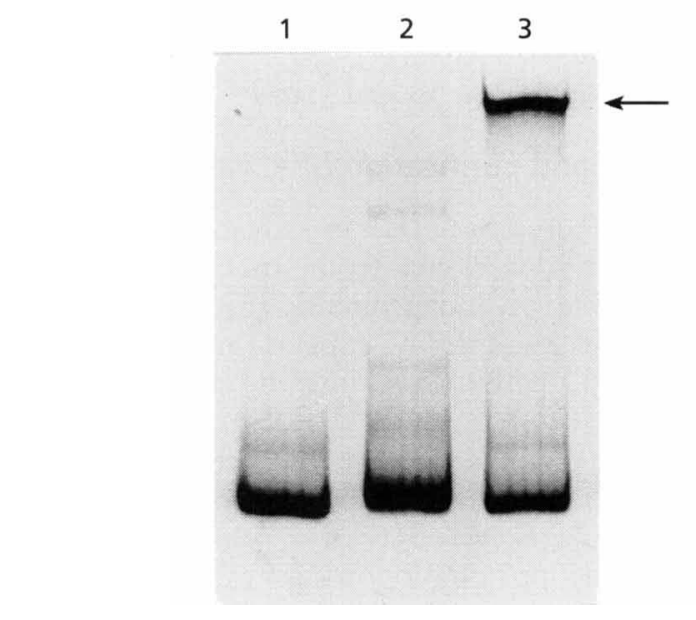

(b)

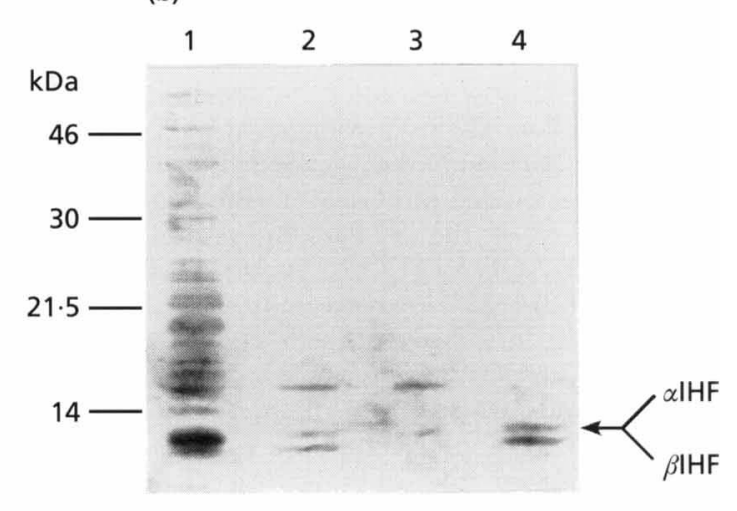

Fig. 1. Purification of overproduced $P$. aeruginosa IHF. (a) Gel-mobility shift assay with the 280 bp DNA fragment of the algB promoter containing the IHF binding site (see Methods). Lanes: 1 , free DNA; 2 , crude extract of $E$. coli JW186 ( $300 \mu \mathrm{g}$ protein); 3 , crude extract of JW186(pAF9) (50 $\mu \mathrm{g}$ protein). (b) SDS-PAGE analysis of the protein fractions obtained during purification. Lanes: 1 , crude cell extract of JW186(pAF9); 2, heparin-Sepharose $0.8 \mathrm{M} \mathrm{NaCl}$ fraction; 3, Mono-S $0.40-0.44 \mathrm{M} \mathrm{NaCl}$ fraction; 4 , Mono-S $0.44-0.48 \mathrm{M} \mathrm{NaCl}$ fraction. The gel was stained with silver nitrate.

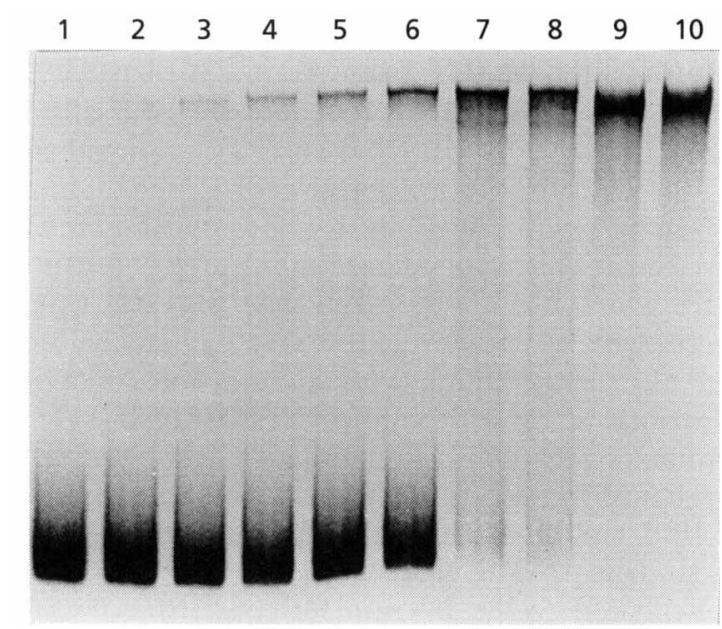

Fig. 2. IHF binding affinity to a fragment of the algD promoter containing two IHF binding sites. The $486 \mathrm{bp}$ algD promoter fragment (approx. $10 \mathrm{fmol}$ ) was incubated in the presence of various concentrations of purified $P$. aeruginosa IHF: $0,5,10$, $20,40,100,200,300,600,1000 \mathrm{nM}$ (lanes 1-10, respectively). Reaction mixtures $(15 \mu \mathrm{l})$ were loaded on $6 \%$ PAGE/0.5 $\times$ TBE.

occupied and that the presence of site 2 did not enhance IHF binding to site 1 .

\section{Intracellular concentration of IHF in P. aeruginosa CHA}

The occupancy of binding sites in vivo may vary with the concentration of IHF in the cell. Indeed, recent studies have demonstrated that the intracellular fluctuation of IHF in E. coli affects several biological functions of that protein (Ditto et al., 1994). The intracellular concentration of $P$. aeruginosa IHF was determined by Western blot analyses with E. coli anti-IHF antibodies. These antibodies recognize both IHF subunits of $P$. aeruginosa (the $\beta$ subunit is less well recognized), as well as the histone-like protein of $9 \mathrm{kDa}, \mathrm{HU}$, which shares significant amino acid homology with IHF. The overproduced IHF protein, purified to homogeneity, was used for calibration (Fig. 3, lanes 1-4). The same amounts of $P$. aeruginosa cells, harvested at different points of growth, were prepared as described by Ditto et al. (1994) and directly loaded onto the gel. As can be seen in Fig. 3, the level of IHF did not change significantly between the early- $\left(\mathrm{OD}_{600} 0 \cdot 1\right)$ and the mid-exponential $\left(\mathrm{OD}_{600} 0 \cdot 8\right)$ phase of growth, but increased more than tenfold when the cells entered the stationary phase $\left(\mathrm{OD}_{600} 2 \cdot 0\right)$. The relative amount of IHF did not change further during late-stationary phase. The estimation of the amount of IHF was based on the facts that: (i) $P$. aeruginosa cultures in the exponential and the stationary phase of growth contain $1.5 \times 10^{9}$ viable cells per $\mathrm{OD}_{600} \mathrm{ml}^{-1}$ unit and (ii) this quantity of cells contains approximately $280 \mu \mathrm{g}$ protein. In the stationary phase, the intracellular concentration of $P$. aeruginosa $\mathrm{IHF}$ was estimated to be $0.2 \mathrm{ng}$ IHF per $\mu$ g total cell protein, that is about one-thirtieth of the IHF concentration in E. coli cells at the same phase of growth (Ditto et al., 1994). The low abundance of IHF in $P$. aeruginosa cells compared to $E$. coli was confirmed by the relative binding activity of IHF in crude extracts. About 20 times more protein from $P$. aeruginosa than from $E$. coli was needed to obtain a similar level of binding (data not shown).

\section{Inactivation of the himA gene in a mucoid strain of $P$. aeruginosa}

In order to investigate the in vivo role of IHF in alginate production, a derivative of the mucoid $P$. aeruginosa strain, CHA, carrying a deletion in the $\operatorname{bim} A$ gene, was 


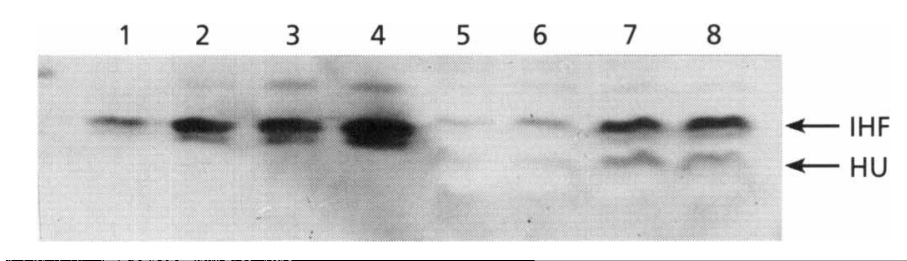

Fig. 3. Determination of the intracellular concentration of $\mathrm{IHF}$ in $P$. aeruginosa CHA cells. Lanes $1-4$, purified IHF protein $(2 \cdot 7,27,136$ and $272 \mathrm{ng}$ protein, respectively). Lanes $5-8$, total extract of CHA cells harvested at an $\mathrm{OD}_{600}$ of $0 \cdot 1$, $0.8,2.0$ and 3.5, respectively, then adjusted to an $\mathrm{OD}_{600}$ of 0.5 . Cells were lysed in the gel-loading buffer, and separated by SDS-PAGE $(0.1 \%$ SDS, $16 \%$ polyacrylamide). Proteins were blotted onto the membrane and developed by antibodies against $E$. coli IHF, as described in Methods. The protein of higher mobility present in $P$. aeruginosa crude extracts which cross-reacts with anti-IHF antibodies corresponds to $P$. aeruginosa $\mathrm{HU}$.

(a)

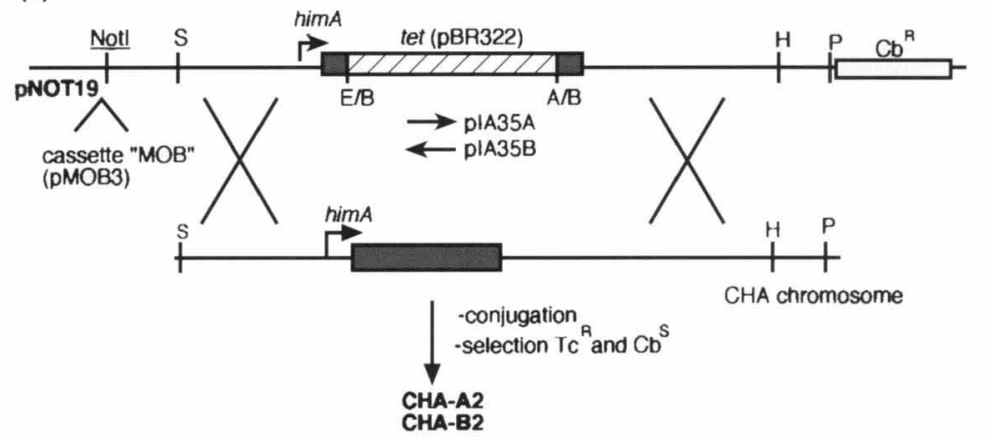

(b)
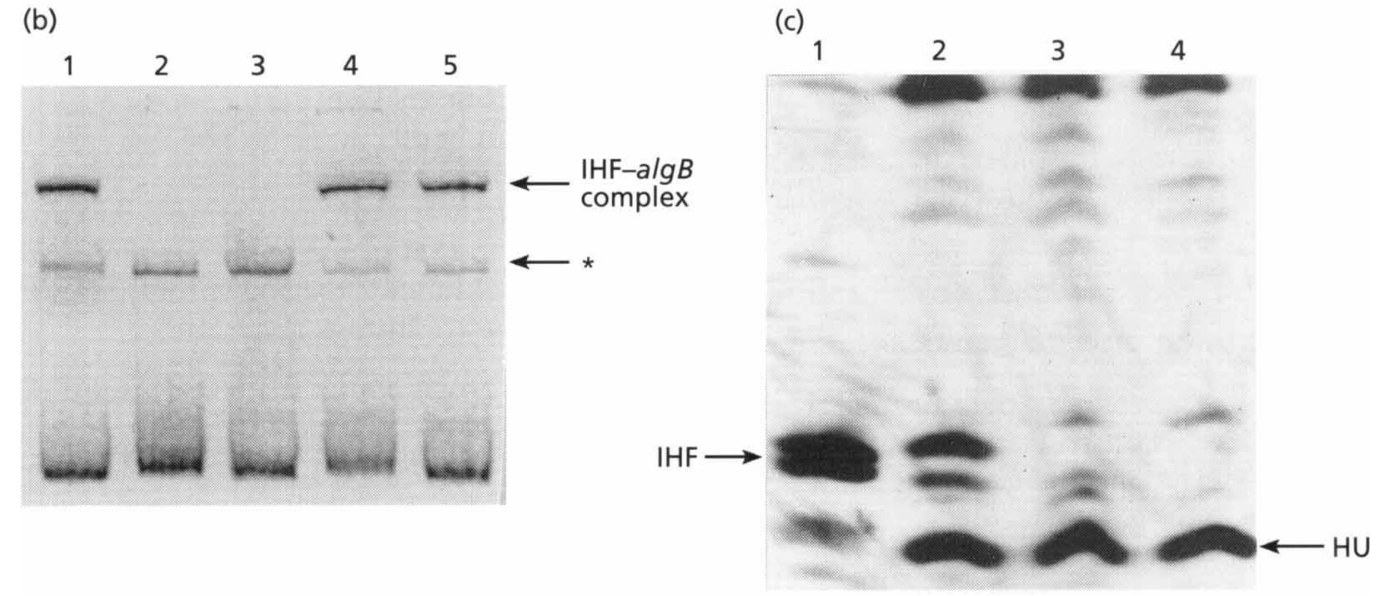

Fig. 4. (a) Construction of $P$. aeruginosa strains $C H A-A 2$ and $C H A-B 2$, mutated in himA, by the allelic exchange technique. A partial restriction map of plasmid pIA35, which contains the inactivated himA gene of $P$. aeruginosa CHA, is shown. Plasmids pIA35A and pIA35B differ in the orientation of the tetracycline (tet) resistance gene inserted into himA. The unique Notl site used to ligate the MOB cassette from $\mathrm{Tc}^{\mathrm{R}}$ and $\mathrm{Cb}^{S}$ resulted in $P$. aeruginosa strains CHA-A2 and CHA-B2. Abbreviations: S, Smal; E, EcoRI; B, BamHI, A, Aval, $\mathrm{H}$, HindIII; $P$, Pstl; $T C^{R}$, resistance to tetracycline; $\mathrm{Cb}^{\mathrm{R}}$, resistance to carbenicillin; $\mathrm{Cb}^{\mathrm{S}}$, sensitivity to carbenicillin. (b) Gelmobility shift assay with an algB DNA fragment. A PCR-generated DNA fragment containing the IHF binding sequence from the algB promoter was labelled and incubated with cell extracts from $P$, aeruginosa CHA (lane 1). CHA-A2 (lane 2), CHA-B2 (lane 3), CHA-A2(p|A282) (lane 4) and CHA-B2(pIA282) (lane 5). The IHF-algB complex is indicated with an arrow. Another complex, indicated with an asterisked arrow, is due to an unidentified protein. (c) Western blot of total cellular protein extracts of $E$. coli and $P$. aeruginosa strains using antibodies against $E$. coli IHF. Lanes: 1, E. coli HB101; $2, P$. aeruginosa CHA; 3, CHA-A2; 4, CHA-B2. The IHF and HU proteins that cross-react with anti-IHF antibodies are indicated.

constructed. Gene replacement in strain CHA was carried out as described in Methods, using plasmids (pIA35A and $\mathrm{B})$ in which the tet gene was inserted in the two opposite orientations with respect to $\operatorname{bim} A$ transcription. Allelic exchange between the CHA chromosome and pIA35 at the $\operatorname{bim} A$ locus takes place by a double recombination event. Strains in which a double crossover had occurred were identified by screening tetracycline-resistant transconjugants for sensitivity to carbenicillin (Fig. 4a). Two carbenicillin-sensitive isolates, designated CHA-A2 and 
CHA-B2, were then tested by Southern hybridization to confirm the presence of the correct $\operatorname{bim} A:$ : tet insertion. The absence of plasmid, and the presence of a single copy of the tet gene inserted in the $\operatorname{bim} A$ gene, were further verified by using either the $\mathrm{MOB}$ cassette from $\mathrm{PMOB} 3$ or the tet gene as a probe (data not shown).

The absence of functional IHF in the mutants was confirmed by gel retardation experiments, using a DNA fragment containing the IHF-binding site from the algB promoter (Fig. 4b). A complex with the same mobility as that formed with purified $P$. aeruginosa IHF was observed with crude extracts from strain CHA, but not with crude extracts from strains CHA-A2 and CHA-B2. This band was restored in the mutant strains complemented with the wild-type $\operatorname{bim} A$ gene cloned on a $1.8 \mathrm{~kb}$ PstI fragment (Fig. 4b, lanes 4 and 5). An additional band, which was observed with extracts from all strains (indicated with an asterisk), is probably due to an additional, unidentified protein, which also binds to the algB promoter (unpublished data).

Further confirmation that the mutants lacked IHF protein was provided by Western blotting using antibodies against E. coli IHF (Fig. 4c). The mutant strains lacked the $\beta$ subunit of IHF (encoded by $\operatorname{bim} D$ ), as well as the $\alpha$ subunit, suggesting that the $\alpha$ subunit is required for the synthesis of the $\beta$ subunit, or to stabilize it, e.g. by heterodimer formation. A decrease in the level of $\beta$ subunit following deletion of $\operatorname{bim} A$ has also been observed in E. coli (Ditto et al., 1994). The HU protein $(9 \mathrm{kDa})$ was present in similar amounts in all strains, showing that IHF deficiency had no effect on the synthesis of $\mathrm{HU}$.

\section{Effect of himA inactivation on algD gene expression}

Transcriptional fusions between the algD promoter and the $x y l E$ reporter gene were constructed, then introduced into the parental strain CHA and the $\operatorname{bim} A$ mutants. The transcriptional activities of palgD were determined by quantitative catechol dioxygenase assays.

Several reports have shown that induction of algD transcription depends on the mucoid status of a given strain and on various environmental stimuli. We observed a tenfold increase in the level of algD transcription in the mucoid strain $\mathrm{CHA}$ when the $\mathrm{NaCl}$ concentration in the medium was increased from 0 to $0.3 \mathrm{M}$ (Fig. 5a), in accordance with earlier results that defined the expression pattern of algD (DeVault et al., 1989). In the $\operatorname{bim} A$ mutants, expression of the palgD-xylE fusion did not differ from that in strain CHA when cells were grown in LB medium without $\mathrm{NaCl}$, but in the presence of $0.3 \mathrm{M} \mathrm{NaCl}$, when algD is fully induced, XylE specific activity in the $\operatorname{bim} A$ mutants was only $25-35 \%$ of that observed in the parental CHA cells. Nevertheless, the level of palg $D$ transcription in the $\operatorname{bim} A$ mutants remained two- to threefold higher than that observed in the parental and the two mutant strains under non-activating conditions (Fig. 5a). This result suggests that IHF is not absolutely required for basal algD expression, but is

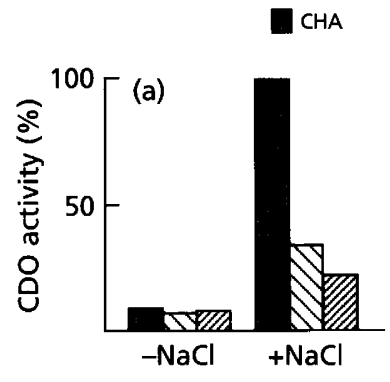

$\triangle$ CHA-A2

Fig. 5. Analysis of algD expression in himA mutants using quantitative catechol dioxygenase $(\mathrm{CDO})$ assays. $P$. aeruginosa strains harbouring the algD-xylE fusion plasmid pIA111 were grown to an identical cell density $\left(O D_{600} 2 \cdot 0\right)$ in $L B$ medium either with or without $0.3 \mathrm{M} \mathrm{NaCl}$ (a), or in minimal medium containing either $\left(\mathrm{NH}_{4}\right)_{2} \mathrm{SO}_{4}$ or $\mathrm{KNO}_{3}$ (each $0.2 \%$ ) as nitrogen source (b). The results shown are means from at least three experiments. Results are plotted as a percentage of the fully induced parental (CHA) activity level; $100 \%$ specific activity corresponded to $19000-21000 \mathrm{mU}\left(\mathrm{mg}^{2} \text { protein }\right)^{-1}$ (a) and 500-700 $\mathrm{mU}$ (mg protein) $)^{-1}$ (b).

necessary for full activation under conditions of high salinity.

Another environmental factor reported to activate $\operatorname{alg} D$ expression is nitrogen limitation (May \& Chakrabarty, 1994a). We measured the activity of the palgD-xylE fusion in minimal medium supplemented either with ammonia or with nitrate as the nitrogen source. In the $\mathrm{IHF}^{+}$parental strain CHA the level of algD transcription was increased tenfold in the medium containing nitrate compared to that in medium containing ammonia, while in the $\operatorname{bim} A$ mutants the alg $D$ promoter was not activated under those conditions (Fig. 5b).

We have shown above that transcriptional activation of the algD gene is affected in the $\operatorname{bim} A$ mutants CHA-A2 and CHA-B2. Since a strong activation of algD is a necessary step in alginate overproduction leading to a mucoid phenotype we examined the synthesis of alginate in the mutant strains. The initial screening of the mutants on agar plates containing tetracycline did not allow us to select double recombinants, such as CHA-A2 and CHA$\mathrm{B} 2$, on the basis of a non-mucoid phenotype. When grown on PIA plates, a medium reported to induce alginate production, the colonies clearly synthesized less alginate than the parental strain, $\mathrm{CHA}$, but were still mucoid. The difference in the mucoid aspect of the colonies was most obvious when $\mathrm{CHA}-\mathrm{A} 2$ and $\mathrm{CHA}-\mathrm{B} 2$ were restreaked on the same PIA plate alongside the parental CHA strain. This difference was quantified by determining the amount of alginate synthesized (Fig. 6). The amount of alginate produced by strain $\mathrm{CHA}$ was comparable to that of other CF isolates (e.g. Deretic et al., 1987). The quantity of alginate synthesized by the mutants was approximately $50 \%$ of that synthesized by the parental strain, CHA. Complementation of the CHA-A2 and CHA-B2 mutants with plasmid pIA282, containing the intact $\operatorname{bim} A$ gene, restored the level of alginate synthesis to the amounts measured in CHA. This shows 


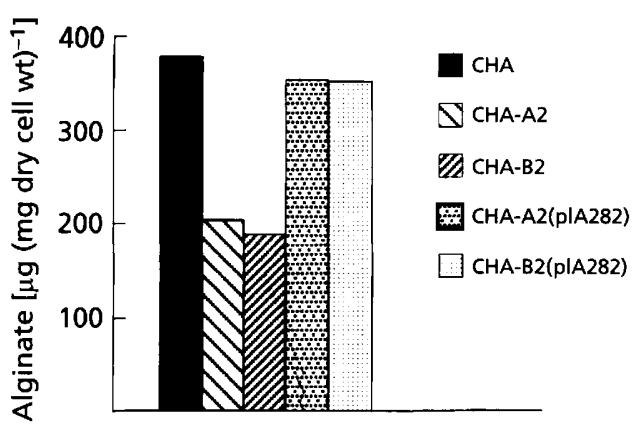

Fig. 6. Alginate production in $P$. aeruginosa strains. Alginate was isolated from cultures grown for $24 \mathrm{~h}$ on PIA plates and its amount determined by the carbazole method (Knutson \& Jeanes, 1968). The results are means from at least three experiments.

that the decrease in alginate synthesis was indeed due to the lack of IHF and not to a secondary mutation.

\section{DISCUSSION}

The results described in this paper confirm and extend the report of Wozniak (1994) concerning the role of IHF in algD gene expression. The two IHF binding sites in the algD promoter were shown to bind purified, recombinant $P$. aeruginosa IHF with $K_{\mathrm{d}}$ values similar to those reported previously for $E$. coli IHF, suggesting that the two proteins have similar binding activity. The $K_{d}$ values of $130 \mathrm{nM}$ for algD IHF site 2 and $1.9 \mu \mathrm{M}$ for algD IHF site 1 determined with $P$. aeruginosa IHF are higher than the 1-20 nM determined for the binding of E. coli IHF to its specific sites (reviewed by Nash, 1996), although values in the range of $100 \mathrm{nM}$ have also been found in $E$. coli (Freundlich et al., 1992).

In late-stationary phase, the IHF concentration in E. coli may be as high as $84 \mu \mathrm{M}$ (Ditto et al., 1994). In the present study, we found that the IHF content of $P$. aeruginosa increased when the cells entered stationary phase, as found in E. coli (Ditto et al., 1994; Aviv et al., 1994), but the level, in the range $200-500 \mathrm{nM}$ in exponential phase and about $3 \mu \mathrm{M}$ in stationary phase, was about 30 times lower than in $E$. coli. The IHF concentration in exponential phase is probably insufficient to saturate both sites in the algD promoter in vivo, even if all the IHF is available for binding. However, the major increase in the intracellular content of IHF occurs at the phase of growth where $\operatorname{alg} D$ transcription and alginate synthesis reach their maximal levels (Leitão \& Sá-Correia, 1995) and may be critical for the in vivo role of IHF in the algD activation.

Mutational analysis of the $\operatorname{algD}$ IHF binding sites has shown that both are required for full-level algD expression (Wozniak, 1994). In the present study, the isolation of an IHF-deficient mutant of $P$. aeruginosa allowed us to confirm the role of IHF protein in algD expression and to examine more clearly the role this protein plays in vivo in the regulation of algD expression and alginate synthesis. The algD gene is highly regulated and its expression is modulated by environmental conditions such as nitrogen limitation, osmolarity or ethanol. It has been established that the topological state of the promoter DNA plays a role in transcriptional activation of environmentally regulated genes (Higgins et al., 1990). It was initially thought that IHF acts essentially as an architectural element, promoting the bending of DNA and allowing the interaction between an activator, bound at sequences known as far upstream sites (FUS) from the transcriptional start site, and $\sigma^{54}$-containing RNA polymerase. Such is the case for nif $H$, which has a $\sigma^{54}$-dependent promoter activated by the NifA regulator, a member of the NtrC subfamily (Hoover et al., 1990). Activation of algD depends on two regulatory proteins, AlgR (Deretic et al., 1989) and AlgB (Wozniak \& Ohman, 1991; Goldberg \& Dahnke, 1992), which both belong to the same NtrC subfamily. However, algD transcription does not require $\sigma^{54}$ but rather the product of $\operatorname{alg} U$. $A \lg \mathrm{U}$ is a sigma factor related to $E$. coli stress-response $\sigma^{\mathrm{E}}$ factor (Deretic et al., 1994; Hershberger et al., 1995). The position of the upstream IHF binding site 1 located between the transcriptional start site and the FUS suggests that IHF functions as an architectural element that enhances the interactions of RNA polymerase with activating proteins, including $A \lg R$. In algR mutants, the activation of $\operatorname{alg} D$ by nitrogen limitation is abolished, but some response to increased osmolarity is still observed (Mohr et al., 1990). Under these two activating conditions, we observed that our IHF mutants were not able to achieve maximal algD transcription. This is the only known example where IHF is involved in the activation of a $\sigma^{\mathbf{E}}$-type promoter. The relatively high residual alg $D$ activity $(25-35 \%)$ measured in the IHF mutants under activating conditions, an activity that correlates with alginate production ( $50 \%$ compared to the parental strain, CHA), can be explained either by a non-specific activation by trans-activators that do not require IHF or by the involvement of other histone-like elements like AlgR3. Indeed, in addition to IHF, several proteins able to bind and bend the $\operatorname{alg} D$ promoter DNA have been identified. The cAMP receptor protein from $E$. coli binds the algD promoter between positions -399 and -288 upstream from the transcriptional start site (DeVault et al., 1991). It has been shown also that the synthetic peptide derived from $\mathrm{AlgR} 3$ (also called $\mathrm{Alg} \mathrm{P}$ ), a $P$. aeruginosa H1-like histone protein, can bind to the algD promoter (Deretic \& Konyecsni, 1990), and a general function for AlgR3 $(\mathrm{A} \lg \mathrm{P})$ in the organization of the bacterial nucleoid has been proposed (Deretic et al., 1992). Although a direct role of a CRP-like protein and of $A \lg R 3(A \lg P)$ in the regulation of $\operatorname{alg} D$ is still questionable, a participation of those proteins in the modulation of the local promoter topology cannot be excluded.

Mutational analysis of IHF site 2, located downstream from +1 of transcription, has shown that site 2 is indeed required for transcriptional activation of alg $D$; furthermore, deletion of the $3^{\prime}$ region downstream from that site resulted in a tenfold decrease in algD expression (Wozniak, 1994). The role of IHF may be to facilitate interactions between a factor bound to a $3^{\prime}$ enhancer and RNA 
polymerase. Preliminary results from our laboratory indicate that IHF binding to site 2 in the palgD $3^{\prime}$ region induces a strong looping out of DNA, an effect consistent with the proposed DNA bending function of IHF. Furthermore, we have recently isolated a DNA-binding protein able to bind specifically to the $3^{\prime}$ palgD region, downstream from IHF site 2, and are currently in the process of characterizing it (unpublished data). This unusual organization of regulatory elements is not unknown for bacterial promoters. Perhaps the best-known example is a developmentally regulated Caulobacter flagellar gene, flaN, whose activation requires both a $3^{\prime}$ enhancer element and an IHF binding site situated just upstream of it (Gober \& Shapiro, 1992).

\section{ACKNOWLEDGEMENTS}

The authors thank Drs H. A. Nash (NIH, Bethesda, USA), J Rouvière-Yaniv (Institut de Biologie Physico-Chimique, Paris) and M.-A. Mandrand (INSA, Lyon) for generous gifts of antiIHF antibodies, E. coli JRY827 and JR826 strains, and phage P1vir, respectively. This work was supported in part by grant from the Association Française de Lutte contre la Mucoviscidose (no. 94003, to B. Toussaint).

\section{REFERENCES}

Aviv, M., Giladi, H., Schreiber, G., Oppenheim, A. B. \& Glaser, G. (1994). Expression of the genes coding for the Escherichia coli integration host factor are controlled by growth phase, rpoS, ppGpp and by autoregulation. Mol Microbiol 14, 1021-1031.

Bradford, M. M. (1976). A rapid and sensitive method for the quantitation of microgram quantities of protein utilizing the principle of protein-dye binding. Anal Biachem 72, 248-254.

Chitnis, C. E. \& Ohman, D. E. (1993). Genetic analysis of the

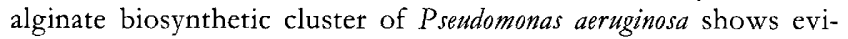
dence of an operonic structure. Mol Microbiol 8, 583-590.

Delic-Attree, I., Toussaint, B. \& Vignais, P. M. (1995). Cloning and sequence analysis of the genes coding for the integration host factor (IHF) and HU and proteins of Pseudomonas aeruginosa. Gene 154, 61-64.

Deretic, V. \& Konyecsni, W. M. (1990). A procaryotic regulatory factor with a histone H1-like carboxy-terminal domain: clonal variation of repeats within algP, a gene involved in regulation of mucoidy in Pseudomonas aeruginosa. J Bacteriol 172, 5544-5554.

Deretic, V., Gill, J. F. \& Chakrabarty, A. M. (1987). Gene algD coding for GDPmannose dehydrogenase is transcriptionally activated in mucoid Pseudomonas aeruginosa. J Bacteriol 169, 351-358.

Deretic, V., Dikshit, R., Konyecsni, W. M., Chakrabarty, A. M. \& Misra, T. K. (1989). The algR gene, which tegulates mucoidy in Pseudomonas aeruginosa, belongs to a class of environmentally responsive genes. J Bacteriol 171, 1278-1283.

Deretic, V., Hibler, N. S. \& Holt, S. C. (1992). Immunocytochemical analysis of $\operatorname{AlgP}\left(\mathrm{H}_{\mathrm{p}} 1\right)$, a histonelike element participating in control of mucoidy in Pseudomonas aeruginosa. J Bacteriol 174, 824-831.

Deretic, V., Schurr, M. J., Boucher, J. C. \& Martin, D. W. (1994). Conversion of Pseudomonas aeruginosa to mucoidy in cystic fibrosis: environmental stress and regulation of bacterial virulence by alternative sigma factors. J Bacteriol 176, 2773-2780.

DeVault, J. D., Berry, A., Misra, T. K., Darzins, A. \& Chakrabarty, A. M. (1989). Environmental sensory signals and microbial patho- genesis: Pseudomonas aeruginosa infection in cystic fibrosis. Bio/ Tecbnology 7, 352-357.

DeVault, J. D., Hendrickson, W., Kato, J. \& Chakrabarty, A. M. (1991). Environmentally regulated $a l g D$ promoter is responsive to the cAMP receptor protein in Escherichia coli. Mol Microbiol 5, 2503-2509.

Ditton, M. D., Roberts, D. \& Weisberg, R. A. (1994). Growth phase variation of integration host factor level in Escherichia coli.J Bacteriol 176, 3738-3748.

Freundlich, M., Ramani, N., Mathew, E., Sirko, A. \& Tsui, P. (1992). The role of integration host factor in gene expression in Escherichia coli. Mol Microbiol 6, 2557-2563.

Gober, J. W. \& Shapiro, L. (1992). A developmentally regulated Caulobacter flagellar promoter is activated by $3^{\prime}$ enhancer and IHF binding elements. Mol Biol Cell 3, 913-926.

Goldberg, J. B. \& Dahnke, T. (1992). Pseudomonas aeruginosa $\mathrm{AlgB}$, which modulates the expression of alginate, is a member of the NtrC subclass of prokaryotic regulators. Mol Microbiol 6, 59-66.

Hershberger, C. D., Ye, R. W., Parsek, M. R., Xie, Z.-D. \& Chakrabarty, A. M. (1995). The algT (algU) gene of Pseudomonas aeruginosa, a key regulator involved in alginate biosynthesis, encodes an alternative $\sigma$ factor $\left(\sigma^{\mathrm{E}}\right)$. Proc Natl Acad Sci US A 92, 7941-7945.

Higgins, C. F., Hinton, J. C. D., Hulton, C. S. J., Owen-Hughes, T., Pavitt, G. D. \& Seirafi, A. (1990). Protein H1 : a role for chromatin structure in the regulation of bacterial gene expression and virulence? Mol Microbiol 4, 2007-2012.

Hoover, T. R., Santero, E., Porter, S. \& Kustu, S. (1990). The integration host factor stimulates interaction of RNA polymerase with NIFA, the transcriptional activator for nitrogen fixation operons. Cell 63, 11-22.

Kato, J., Misra, T. K. \& Chakrabarty, A. M. (1990). AlgR3, a protein resembling eukaryotic histone $\mathrm{H} 1$, regulates alginate synthesis in Pseudomonas aeruginosa. Proc Natl Acad Sci US A 87, 2887-2891.

Knutson, C. A. \& Jeanes, A. (1968). A new modification of the carbazole analysis: application to heteropolysaccharides. Anal Biocbem 24, 470-481.

Konyecsni, W. M. \& Deretic, v. (1988). Broad-host-range plasmid and M13 bacteriophage-derived vectors for promoter analysis in Escherichia coli and Pseudomonas aeruginosa. Gene 74, 375-386.

Krieg, D. P., Helmke, R. J., German, R. F. \& Mangos, J. A. (1988). Resistance of mucoid Pseudomonas aeruginosa to nonopsonic phagocytosis by alveolar macrophages in vitro. Infect Immun 28, 546-556. Laemmli, U. K. (1970). Cleavage of structural proteins during the assembly of the head of bacteriophage T4. Nature 227, 680-685.

Leitão, J. H. \& SáCorreia, I. (1995). Growth-phase-dependent alginate synthesis, activity of biosynthetic enzymes and transcription of alginate genes in Pseudomonas aeruginosa. Arch Microbiol 163, 217-222

May, T. B. \& Chakrabarty, A. M. (1994a). Pseudomonas aeruginosa: genes and enzymes of alginate synthesis. Trends Microbiol 2, 151-157.

May, T. B. \& Chakrabarty, A. M. (1994b). Isolation and assay of Pseudomonas aeruginosa alginate. Methods Enyymol 235, 295-304.

May, T. B., Shinabarger, D., Maharaj, R., Kato, J., Chu, L., DeVault, J. D., Roychoudhury, S., Zielinski, N., Berry, A., Rothmel, R. K., Misra, T. K. \& Chakrabarty, A. M. (1991). Alginate synthesis in Pseudomonas aeruginosa: a key pathogenic factor in chronic pulmonary infections of cystic fibrosis patients. Clin Microbiol Rev 4, 191-206

Miller, J. H. (1972). In Experiments in Molecular Genetics, pp. 45494557. Cold Spring Harbor, NY: Cold Spring Harbor Laboratory. Mohr, C. D., Martin, D. W., Konyecsni, W. M., Govan, J. R. W., 
Lory, S. and Deretic, V. (1990). Role of the far-upstream sites of the algD promoter and the $\operatorname{algR}$ and $r p o N$ genes in environmental modulation of mucoidy in Pseudomonas aeruginosa. J Bacteriol 172, 6576-6580.

Nash, H. A. (1996). The E. coli HU and IHF proteins: accessory factors for complex protein-DNA assemblies. In Regulation of Gene Expression in Escherichia coli. Edited by E. C. C. Lin \& A. S. Lynch. Austin, TX: R. G. Landes (in press).

Sambrook, J., Fritsch, E. F. \& Maniatis, T. (1989). Molecular Cloning: a Laboratory Manual. Cold Spring Harbor, NY: Cold Spring Harbor Laboratory.

Sanger, F., Nicklen, S. \& Coulson, A. R. (1977). DNA sequencing with chain-terminating inhibitors. Proc Natl Acad Sci USA 74, 5463-5467.

Slack, M. P. E. \& Nichols, W. W. (1981). The penetration of antibiotics through sodium alginate and through the exopolysaccharide of a mucoid strain of Pseudomonas aeruginosa. Lancet ii, 502-503.

Schweizer, H. P. (1992). Allelic exchange in Pseudomonas aeruginosa using novel ColE1-type vectors and a family of cassettes containing a portable oriT and the counter-selectable Bacillus subtilis sac $B$ marker. Mol Microbiol 6, 1195-1204.

Studier, F. W., Rosenberg, A. H., Dunn, J. J. \& Dubendorff, J. W. (1990). Use of T7 RNA polymerase to direct expression of cloned genes. Methods Enzymol 185, 60-89.

Toussaint, B., Delic-Attree, I. \& Vignais, P. M. (1993a). Pseudomonas aeruginosa contains an IHF-like protein that binds to the algD promoter. Biochem Biophys Res Commun 196, 416-421.

Toussaint, B., Delic-Attree, I., de Sury d'Aspremont, R., David, L., Vinçon, M. \& Vignais, P. M. (1993b). Purification of the Integration Host Factor homolog of Rbodobacter capsulatus: cloning and sequencing of the bip gene, which encodes the $\beta$ subunit. $J$ Bacteriol 175, 6499-6504.

Vogel, H. J. \& Bonner, D. M. (1956). Acetylornithinase of Escherichia coli: partial purification and some properties. $J$ Biol Chem 218, 97-106.

West, S. E. H., Schweizer, H. P., Dall, C., Sample, A. K. \& RunyenJanecky, L. J. (1994). Construction of improved Escherichia$P_{\text {seudomonas shuttle vectors derived from pUC18/19 and sequence }}$ of the region required for their replication in Pseudomonas aeruginosa. Gene 128, 81-86.

Wozniak, D. J. (1994). Integration host factor and sequences downstream of the Pseudomonas aeruginosa algD transcription start site are required for expression. $J$ Bacteriol 176, 5068-5076.

Wozniak, D. J. \& Ohman, D. E. (1991). Pseudomonas aeruginosa $\mathrm{AlgB}$, a two-component response regulator of the $\mathrm{NtrC}$ family, is required for algD transcription. $J$ Bacteriol 173, 1406-1413.

Wozniak, D. J. \& Ohman, D. E. (1993). Involvement of the alginate alg $T$ gene and integration host factor in the regulation of the Pseudomonas aeruginosa algB gene. J Bacteriol 175, 4145-4153.

Received 15 January 1996; revised 3 April 1996; accepted 31 May 1996. 